\title{
Pemberdayaan Masyarakat melalui Pengelolaan Sampah Berbasis Ecovillage di Desa Penebel, Kecamatan Penebel, Kabupaten Tabanan, Bali
}

\author{
${ }^{1}$ Dewa Ayu Putu Adhiya Garini Putri, ${ }^{2}$ Gusi Putu Lestara Permana \\ 1,2Universitas Pendidikan Nasional \\ adhiyagariniputri@undiknas.ac.id; lestarapermana@undiknas.ac.id
}

\begin{abstract}
Abstrak
Desa Penebel merupakan salah satu desa yang berada di Kabupaten Tabanan yang saat ini sedang berupaya untuk mandiri dalam manajemen pengelolaan sampah. Selain untuk menjaga dan melestarikan lingkungan yang bersih dan sehat, manajemen pengelolaan sampah juga dapat memberikan dampak yang positif bagi masyarakat baik dari sisi ekonomi ataupun penataan lingkungan menjadi lebih tertata. Saat ini manajemen pengelolaan sampah terpusat pada area Kantor Desa Penebel, namun karena minimnya sarana dan prasarana penunjang dalam upaya pengelolaan sampah menjadi tidak maksimal. Kegiatan pengelolaan sampah yang berbasis ecovillage ini bertujuan untuk meningkatkan kesadaran masyarakat terhadap pentingnya melakukan pengelolaan sampah dan menjaga kualitas lingkungan yang berkelanjutan di Desa Penebel. Adapun bentuk kegiatan yang dilakukan adalah diskusi dan partisipasi aktif dari masyarakat sekitar dan kelompok masyakarat yang terlibat dalam pengelolaan sampah tersebut. Hasil yang diharapkan adalah masyarakat sasaran lebih memahami metode pengelolaan sampah, baik organik maupun non organik, sehingga nantinya akan masyarakat secara sadar akan melakukan manajemen pengelolaan sampah secara mandiri.

Kata Kunci : ecovillage, sampah, lingkungan.
\end{abstract}

\section{Pendahuluan}

Keberagaman aktivitas manusia menimbulkan berbagai kegiatan yang bersifat positif dan negative bagi kehidupan ekosistem di bumi. Berdasarkan laporan yang dirilis oleh The Intergovernmental Science-Policy Platform on Biodiversity and Ecosystem Service (IPBES) pada tahun 2019, terdapat lima faktor utama yang menyebabkan dampak negative bagi keanekaragaman hayati global yang disebabkan oleh aktivitas manusia diantaranya adalah perubahan fungsi lahan, eksploitasi pada organisme bumi, perubahan iklim, spesies invasive dan polusi. Polusi menjadi salah satu bagian yang penting untuk diperhatikan, mengingat polusi sangat erat kaitanya dengan sampah dan limbah. Aktivitas kehidupan manusia tentu tidak lepas dari pemasalahan sampah. Berdasarkan data dari Kementerian Lingkungan Hidup dan Kehutanan (KLHK) pada tahun 2019, rata-rata jumlah produksi sampah di Indonesia mencapai 175.000 ton per hari atau setara dengan 64 juta ton per tahunnya. Hal ini diprediksi akan terus bertambah seiring dengan pertambahan jumlah penduduk setiap tahunnya.

Pertumbuhan di berbagai sektor industri di Indonesia juga memberikan sumbangan angka untuk peningkatan pendapatan rumah tangga. Hal ini tentunya akan berdampak pada peningkatan produksi sampah baik dari sisi volume, jenis dan karakteristik sampah tersebut. 
Untuk meminimalisir timbulan sampah, pemerintah melalui Undang-Undang Republik Indonesia Nomor 18 tahun 2008 Tentang Pengelolaan Sampah menjamin terselenggaranya pengelolaan sampah yang baik dan berwawasan lingkungan. Kegiatan yang dilakukan diantaranya adalah meningkatkan kesadaran masyarakat dalam pengelolaan sampah, melakukan penelitian dan pengembangan teknologi pengurangan dalam penanganan sampah dan mendorong serta memfasilitasi pengembangan manfaat hasil pengolahan sampah. Dalam target Sustainable Development Goals (SDGs), upaya penanganan sampah dan limbah setiap negara diharapkan akan mengurang produksi sampah dan limbah melalui upaya yang dikenal dengan istilah 3R yaitu Reduce, Recycle, dan Reuse untuk dapat menjamin pola produksi dan konsumsi yang berkelanjutan.

Peraturan Gubernur Provinsi Bali Nomor 47 tahun 2019 mengenai Pengelolaan Sampah Berbasis Sumber, pengelolaan sampah tidak hanya menjadi tugas pemerintah namun diperlukan peran serta masyarakat untuk ikut dan turut mengambil bagian dalam melakukan pengelolaan sampah. Peran serta masyarakat dibutuhkan untuk merealisasikan kegiatan, mengingat sumber utama produksi sampah adalah rumah tangga. Sampah yang timbul akibat limbah rumah tangga dan pola konsumsi masyarakat harus diselesaikan langsung pada sumbernya sehingga sampah tersebut tidak menjadi beban tempat pembuangan akhir. Hal ini menjadi salah satu upaya yang dapat dilakukan dalam pengelolaan sampah. Salah satu instansi pemerintah yang saat ini sedang gencar yang melakukan upaya-upaya peningkatan kesadaran masyarakatnya terkait dengan pengelolan sampah adalah Pemerintah Desa Penebel.

Pemerintah Desa Penebel saat ini sedang berupaya melakukan pemberdayaan masyarakat dalam manajemen pengelolaan sampah secara mandiri berskala desa. Selain untuk menjaga dan melestarikan lingkungan yang bersih dan sehat, manajemen pengelolaan sampah juga dapat memberikan dampak yang positif bagi masyarakat baik dari sisi ekonomi ataupun penataan lingkungan menjadi lebih tertata. Berbagai kegiatan dilakukan oleh Pemerintah Desa Penebel dan Undiknas seperti edukasi masyarakat terhadap pentingnya juga berperan aktif melakukan kegiatan diskusi dan seminar untuk memberikan edukasi kepada masyarakat tentang pentingnya menjaga lingkungan dari timbulan sampah.

Saat ini manajemen pengelolaan sampah terpusat pada area Kantor Desa Penebel, namun karena minimnya sarana dan prasarana penunjang dalam upaya pengelolaan sampah menjadi tidak maksimal. Kegiatan pengelolaan sampah yang berbasis ecovillage ini bertujuan untuk meningkatkan kesadaran masyarakat terhadap pentingnya melakukan pengelolaan sampah dan menjaga kualitas lingkungan yang berkelanjutan di Desa Penebel.

Lokasi kegiatan pengabdian masyarkat dilakukan pada Desa Penebel, Kecamatan Penebel, Kabupaten Tabanan Provinsi Bali. Kegiatan utama berupa sosialisasi kepada 
masyarakat desa difokuskan pada Aula Kantor Desa Penebel. Sedangkan kegiatan pelatihan dan workshop dilakukan pada area tempat pengolahan sampah (TPS) Desa Penebel yang terletak kurang lebih sekitar 500 m dari Kantor Desa Penebel. Adapun kegiatan ini dilakukan selama rentang waktu bulan desember 2019 hingga februari 2020.

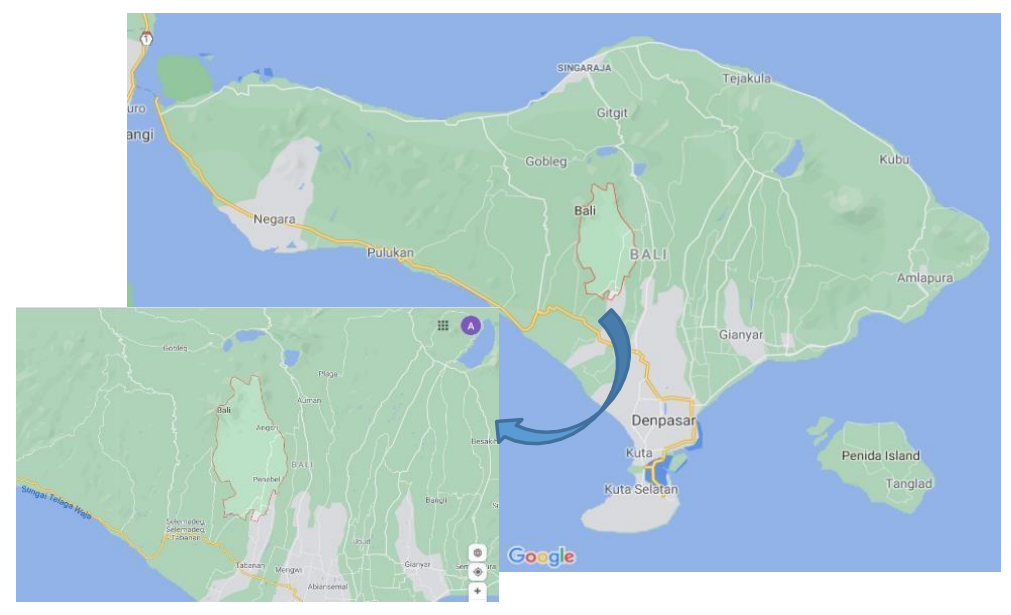

Gambar 1. Denah Lokasi pelaksanaan Kegiatan Pengabdian Masyarakat

\section{Metode Pelaksanaan}

Metode pelaksanaan kegiatan pengabdian masyarakat adalah melakukan penyuluhan terhadap masyarakat Desa Penebel untuk peningkatan kesadaran dalam pentingnya menjaga kebersihan lingkungan dengan melakukan pengelolaan sampah berbasis $3 R$ (Reduce, Reuse, dan Recycle) ditingkat rumah tangga.

\section{Rancangan Pelaksanaan Kegiatan Pengabdian Masyarakat}

Rancangan pelaksanaan kegiatan pengabdian masyarakat di Desa Penebel dilakukan antara lain :

- Perencanaan dan Persiapan

Perencanaan kegiatan dimulai dengan berkoordinasi dengan pihak kepala desa

Penebel. Selain itu, dalam tahap perencanaan juga dilakukan persiapan tempat, alat dan rancangan solusi yang akan disampaikan pada saat sosialisasi.

- Kegiatan Sosialisasi dan Pendampingan

Kegiatan sosialisasi dilakukan kepada masyarakat Desa Penebel dengan beberapa topik pembahasan diantara adalah :

1. Sosialisasi mengenai pentingnya menjaga kebersihan lingkungan

2. Sosialisasi mengenai jenis-jenis sampah rumah tangga

3. Sosialisasi mengenai pengelolaan sampah berbasis $3 R$.

Kegiatan pendampingan dilakukan secara situasional dan berkala dengan memberikan 


\section{Jcommdev}

JCommdev- JOURNAL OF COMMUNITY DEVELOPMENT \& EMPOWERMENT

konsultasi pada masyarakat ataupun perangkat desa yang membutuhkan saran terhadap pengelolaan sampah dilingkungan Desa Penebel.

- Evaluasi Kegiatan

Evaluasi kegiatan dilakukan dengan melakukan wawancara kepada masyarakat yang menjadi peserta sosialisasi. Evaluasi dilakukan untuk mengetahui keberhasilan kegiatan yang dilakukan.

- Sasaran Kegiatan

Sasaran Kegiatan ini adalah masyarakat dilingkungan Desa Penebel yang terdiri dari kelompok ibu-ibu PKK, perangkat desa dan organisasi masyarakat dilingkungan Desa Penebel.

\section{Hasil dan Output}

\section{Gambaran Umum Mitra}

Desa Penebel merupakan ibukota kecamatan penebel, dimana desa ini memiliki luas wilayah seluas 4,56 km. Berdasarkan data yang dirilis oleh Badan Pusat Statistik tahun 2019, jumlah penduduk desa penebel saat ini berjumlah 4.487 jiwa yang terbagi dalam 9 banjar. Desa Penebel saat ini sedang berfokus melakukan upaya peningkatan kebersihan di lingkungan desa dengan cara pengelolaan sampah secara mandiri ditingkat desa. Pengelolaan sampah di Desa Penebel saat ini dilakukan secara swadaya masyarakat. Aparat Desa Penebel sedang berupaya meningkatkan kesadaran masyarakat untuk melakukan pengelolan sampah secara mandiri dan mengurangi timbulan sampah plastik.

Permasalahan yang dihadapi pada Desa Penebel salah satunya adalah tidak memiliki tempat pembuangan akhir. Selain itu perilaku masyarakat yang berpotensi merusak lingkungan seperti melakukan pembakaran sampah dan membuang sampah ke sungai. Hal ini tentunya akan memberikan dampak yang buruk bagi lingkungan sekitar. Tidak hanya itu seiring dengan pertumbuhan jumlah penduduk dikhawatir tingkat timbulan sampah juga semakin meningkat. Sehingga Pemerintah Desa Penebel merasa perlu untuk memulai meningkatkan kesadaran masyarakat terhadap pentingnya menjaga kebersihan lingkungan.

\section{Pelaksanaan Kegiatan}

Sosialisasi kegiatan ini dilakukan kepada perangkat desa dan masyarakat, dengan materi seperti pentingnya menjaga Kesehatan dan kebersihan lingkungan, jenis-jenis sampah yang dihasilkan oleh masyarakat dan pengelolaan sampah berbasis 3R. Pentingnya memberikan edukasi kepada masyarakat adalah yntuk membentuk sikap seseorang untuk melakukan Tindakan atau perilaku. Edukasi dilakukan bertujuan untuk meningkatkan kesadaran masyarakat sekitar terhadap penting melakukan pengelolaan sampah menggunakan metode Reduce, Reuse, dan Recycle). 


\section{all \\ Jcommdev}

JCOMmdeV- JOURNAL OF COMMUNITY DEVELOPMENT \& EMPOWERMENT

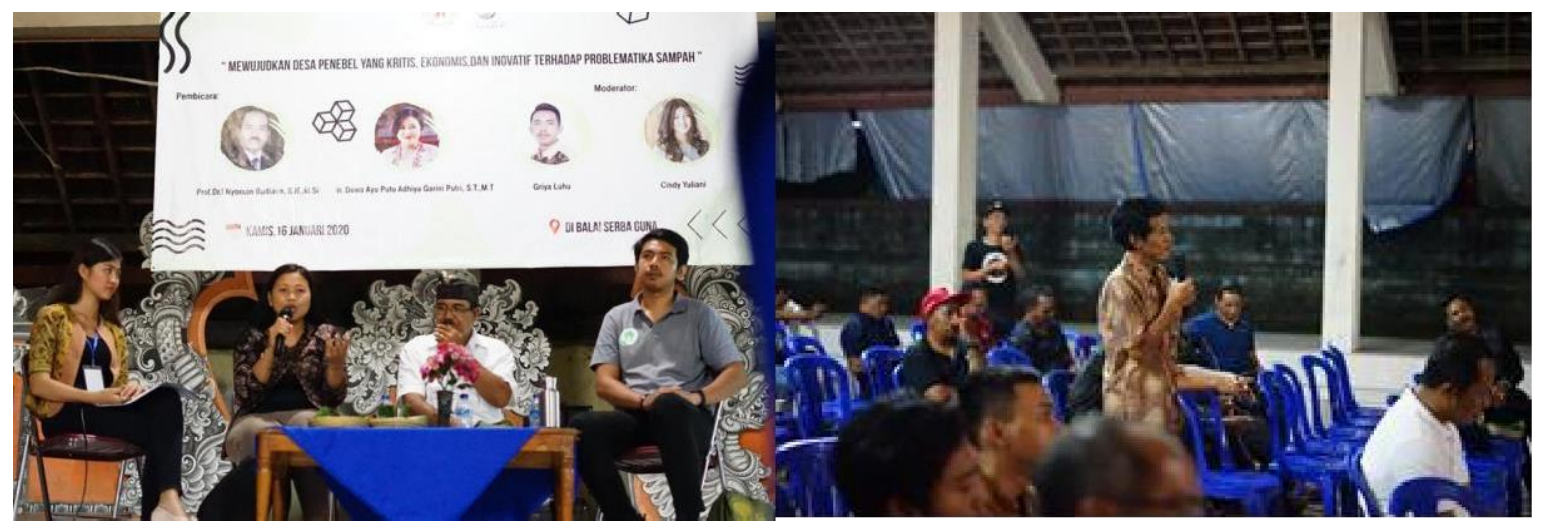

Gambar 2. Pelaksanaan Sosialisasi Kegiatan Pengabdian Masyarakat

Selain itu dilakukan pula pendampingan dan konsultasi teknis bagi aparat dan masyarakat desa mengenai masalah-masalah yang mungkin terjadi dalam implementasi program. Hal ini untuk membantu masyarakat dalam mencari solusi aplikatif yang paling memungkinkan untuk dapat diimplementasikan pada masyarakat. Seperti salah satu contohnya adalah potensi pengembangan bank sampah dan pengolah pupuk cair yang dapat dilakukan oleh pengelola dan aparat desa setempat.

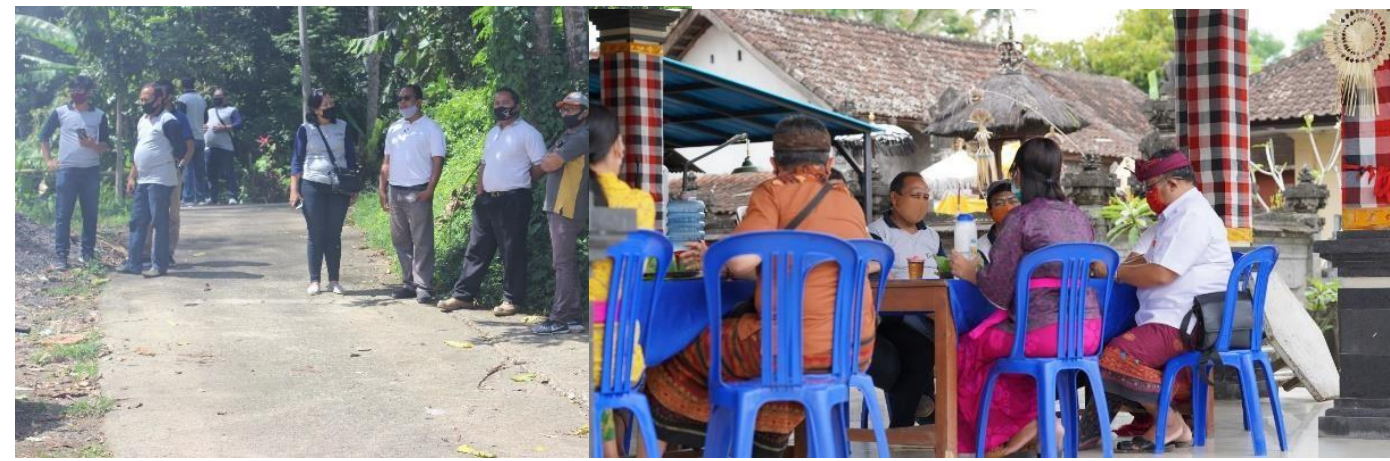

Gambar 3. Pelaksanaan Pendampingan dan Konsultasi Teknis

\section{Monitoring dan Evaluasi Kegiatan}

Monitoring dan evaluasi kegiatan dilakukaan dengan melakukan wawancara mendalam terhadap masyarakat yang telah mengikuti sosialisasi kegiatan pengelolaan sampah 3R. Pada awal kegiatan masyarakat cenderung belum memahami konsep pengelolaan sampah 3R, sehingga masyarakat cenderung masih membuang sampah sembarangan. Setelah sosialisasi dilakukan, monitoring dan evaluasi kegiatan dilakukan selama masa 30 hari. Berdasarkan hasil wawancara diketahui sebagaian besar masyarakat sudah mulai memahami pentingnya menjaga kebersihan lingkungan terbukti dengan adanya 


\section{Jcommdev}

JCOMmdev- JOURNAL OF COMMUNITY DEVELOPMENT \& EMPOWERMENT

inisiatif dari aparat desa masyarkat untuk membuat tanda larangan pada sungai dan tempat pengumpulan sampah illegal di sekitar Desa Penebel. Tidak hanya itu, masyarakat desa penebel juga membentuk organisasi yaitu Relawan Desa Resik Penebel (RED REBEL) yang bertujuan untuk membantu masyarakat untuk melakukan kegiatan rutin seperti pembersihan area sungai disetiap minggunya, melakukan pembersihan area tempat suci dari sampah plastik dan kegiatan lainnya dalam upaya meminimalisir timbulan sampah.

\section{Simpulan dan Saran}

Program Pengabdian Masyarakat di Desa Penebel telah dilakukan dan memberikan solusi bagi beberapa permasalahan sampah. Solusi yang dapat diaplikasikan diantaranya adalah bahwa meningkatnya kesadaran masyarakat dalam menjaga kesehatan lingkungan, hal ini terbukti dengan adanya inisiasi dari aparat dan masyarakat desa untuk membuat tanda larangan pada sungai dan tempat pengumpulan sampah ilegal. Manfaat lainnya adalah terbentuknya organisasi yang dapat mengkoordinir dan membantu masyarakat untuk dengan rutin melaksanakan giat bersih pada fasilitas-fasilitas umum seperti pura, aula pertemuan kantor desa dan lainnya.

\section{Daftar Pustaka}

Kementerian Lingkungan Hidup dan Kehutanan (KLHK). 2019. Data Timbulan Sampah. Kementerian Pekerjaan Umum. 2010. Modul Sampah Berbasis 3R.

Peraturan Gubernur Provinsi Bali. 2019. Peraturan Gubernur Provinsi Bali Nomor 47 tahun 2019 mengenai Pengelolaan Sampah Berbasis Sumber.

The Intergovernmental Science-Policy Platform on Biodiversity and Ecosystem Service (IPBES) pada tahun 2019.

Undang-Undang Republik Indonesia. 2008. Undang-undang Nomor 18 tahun 2008 Tentang Pengelolaan Sampah. 